\title{
UPAYA MENINGKATKAN HASIL BELAJAR PESERTA DIDIK DENGAN MENGGUNAKAN MODEL MIND MAPPING (PETA PIKIRAN) DAN BANTUAN MEDIA AUDIO VISUAL PADA MATA PELAJARAN IPA DI KELAS III SDN 3 LANGKAI PALANGKARAYA
}

\author{
Oleh \\ Rizki Handayani Majid ${ }^{1}$, M. Ramli² \\ email:m.ramli@gmail.com
}

\begin{abstract}
This study aims to determine the increase in learning outcomes and learning activities of Class III SDN 3 Langkai Palangkaraya students in science learning by applying the Mind Mapping Model and assisted by audio visual media. The type of research used in the research is class action research (CAR) which seeks to solve or answer the problems faced in the current situation. The subject of this study amounted to 24 male students 13 and women 11. Data collection techniques used were observation and tests. Techniques for analyzing qualitative and quantitative data. The results of the study concluded that the learning activities of students in science learning by applying the Mind Mapping model and assisted by Audio Visual media of class III students in SDN-3 began to obtain an average score of 77.91 with good criteria. The pre test test results with an average value of 54.79 with classical completeness $(8.33 \%)$ and the results of the first cycle obtained an average score of 77.91 with classical completeness (83.33\%). Cycle II obtained an average value of 85 with classical completeness (100\%).
\end{abstract}

(C) Muhammadiyah University Palangkaraya

Keywords: Learning Outcomes Science, Mind Mapping Model, Audio Visual

\begin{abstract}
ABSTRAK
Penelitian ini bertujuan untuk mengetahui peningkatan hasil belajar dan aktivitas Belajar peserta didik Kelas III SDN 3 Langkai Palangkaraya pada pembelajaran IPA dengan Menerapkan Model Mind Mapping (Peta Pikiran) dan berbantuan media audio visual. Jenis penelitian yang digunakan dalam penelitian adalah penelitian tindakan kelas (PTK) yang berusaha untuk memecahkan atau menjawab permasalahan yang dihadapi pada situasi sekarang. Subjek penelitian ini berjumlah 24 orang peserta didik laki-laki 13 dan perempuan 11. Teknik pengumpulan data yang digunakan yaitu observasi dan tes. Teknik analisis data kualitatif dan kuantitatif. Hasil penelitian disimpulkan bahwa Aktifitas belajar peserta didik dalam pembelajaran IPA dengan menerapkan model Mind Mapping (Peta Pikiran) dan berbantuan media Audio Visual peserta didik kelas III di SDN-3 Langkai memperoleh skor nilai rata-rata 77,91 dengan kriteria baik. Hasil tes pre test dengan nilai rata-rata yaiu 54,79 dengan ketuntasan klasikal $(8,333 \%)$ dan pada hasil siklus I memperoleh nilai rata-rata 77,91 dengan ketuntasan klasikal $(83,33 \%)$. Siklus II memperoleh nilai rata-rata 85 dengan ketuntasan klasikal (100\%).
\end{abstract}

(C) Universitas Muhammadiyah Palangkaraya

Kata Kunci: Hasil Belajar IPA, Model Mind Mapping, Audio Visual 


\section{PENDAHULUAN}

Pendidikan merupakan usaha, pengaruh, perlindungan dan bantuan yang diberikan kepada anak tertuju kepada kedewasaan anak itu, atau lebih tepat membantu anak agar cukup cakap melaksanakan tugas hidupnya sendiri. Pengaruh itu datangnya dari orang dewasa (atau yang diciptakan oleh orang dewasa seperti sekolah, buku, putaran hidup sehari-hari, dan sebagainya) dan ditujukan kepada orang belum dewasa.

Undang-undang RI Nomor 20 Tahun 2003 tentang Sisdiknas, Pasal 1 Ayat 1 (Depdiknas, 2013) adalah : Pendidikan adalah usaha sadar dan terencana untuk mewujudkan suasana belajar dan proses pembelajaran agar peserta didik secara aktif mengembangkan potensi dirinya untuk memiliki kekuatan spritual keagamaan, pengendalian diri, kepribadian, kecerdasan, akhlak mulia, serta keterampilan yang diperlukan dirinya, masyarakat, bangsa, dan negara.

Pendidikan nasional perlu berjalan sesuai dengan tujuan yang ingin dicapai. Pencapaian tujuan pendidikan tersebut, dapat terbentuk melalui pendidikan dasar. Hal ini sesuai dengan Peraturan Menteri Pendidikan Nasional nomer 3 tahun 2006 tanggal 23 Mei 2006 yang menyatakan bahwa pendidikan dasar bertujuan untuk meletakan dasar kecerdasan pengetahuan, kepribadian, akhlak mulia, serta keterampilan untuk hidup mandiri dan mengikuti pendidikan lebih lanjut. Salah satu instansi pendidikan dasar tersebut adalah Sekolah Dasar (SD).
Dari keselurahan proses disekolah dasar (SD), kegiatan belajar merupakan kegiatan utama. Hal ini berarti berhasil atau tidaknya pencapaian tujuan pembangunan nasional banyak tergantung pada proses pembelajaran yang dijalani oleh peserta didik. Belajar memerlukan kesiapan peserta didik dalam mengikuti pelajaran dikelas maupun belajar secara mandiri dirumah. Berkaitan dengan kesiapan belajar, salah satu hal penting yang perlu diperhatikan adalah kesiapan fisik dan mental. Tugas seorang guru adalah menyampaikan materi pelajaran kepada peserta didik melalui interaksi komunikasi dalam proses belajar mengajar yang dilakukannya. Guru hendaknya dapat menggunakan peralatan yang lebih ekonomis, efisien dan mampu dimiliki oleh sekolah serta tidak menolak untuk digunakan peralatan teknologi modern yang relevan dengan tuntunan masyarakat dan perkembangan zaman. Pada zaman sekarang masih banyak guru yang kurang mengerti dengan penggunaan teknologi yang modern seperti OHP, Proyektor dan sebagainya.

IPA merupakan salah satu kegiatan yang akan dilakukan didalam kehidupan sehari-hari setiap orang. Yaitu materi Energi dan Pengaruhnya dalam kehidupan sehari-hari peserta didik di sekolah bisa secara langsung mempraktekan dan melihat memperhatikan media yang dibawa guru.

Berdasarkan kenyataan bahwa pelajaran IPA adalah sesuatu hal yang penting di kembangkan sejak dini, maka peneliti melakukan observasi di kelas III 
SDN 3 Langkai Palangkaraya pada di kelas III SDN 3 Langkai Palangkaraya. Hasil observasi yang dilakukan peneliti di kelas III SDN 3 Langkai Palangkaraya tersebut, peneliti menemukan masalah dimana masih banyak peserta didik yang kurang bersemangat dan banyak yang belum paham dalam mengikuti pelajaran IPA dikarenakan guru kurang menggunakan model, atau media bervariasi saat pembelajaran berlangsung. Peneliti juga menemukan masalah lain seperti peserta didik yang bermalas-malasan materi pelajaran yang di berikan guru, bahkan ada juga peserta didik yang mengobrol dengan teman sebangkunya apa yang telah dijelaskan oleh guru. Berdasarkan hasil observasi pendidik belum mengembangkan model pembelajaran yang bervariasi sehingga mengakibatkan peserta didik mengalami kebosanan dalam belajar sehingga berdampak pada hasil belajar IPA peserta didik dibawah KKM. Hasil belajar IPA kelas III memperoleh nilai standar KKM yaitu 70. Di ketahui bahwa dalam proses pembelajaran IPA kelas III nilai yang diperoleh peserta didik masih ada yang dibawah nilai 70 . Dimana jumlah peserta didik 24 orang sekitar 47,6\% yaitu 10 orang peserta didik masih dibawah nilai Kriteria Ketuntasan Minimal (KKM) dan sekitar $52,3 \%$ yaitu 14 orang peserta didik yang mencapai Kriteria Ketuntasan Minimal (KKM).

\section{METODE PENELITIAN}

Metode penelitian yang digunakan dalam Penelitian ini adalah Penelitian Tindakan Kelas (PTK). Menurut
(Kunandar, 2012:46) bahwa "mendefinisikan Penelitian Tindakan Kelas (PTK) adalah penelitian untuk membantu seseorang dalam mengatasi secara praktis persoalan yang dihadapi dalam situasi darurat dan membantu pencapaian tujuan ilmu sosial dengan kerja sama dalam kerangka etika yang disepakati bersama.

Sementara menurut Burns (Wina Sanjaya 2013 : 24) "Penelitian tindakan kelas adalah suatu penerapan berbagai fakta yang ditemukan untuk memecahkan masalah dalam situasi social untuk meningkatkan kualitas tindakan yang dilakukan dengan melibatkan kolaborasi dan kerja sama para penelitian dan praktisi”.

Berdasarkan jenis penelitian yang digunakan yaitu Penelitian Tindakan Kelas (PTK), maka kehadiran dan peran peneliti adalah sebagai orang yang menyadari adanya permasalahan dalam proses belajar mengajar di kelas, karena peneliti juga berperan sebagai perencana, pelaksana tindakan, pengamat, pengumpul dan penganalisis data serta sebagai pelapor hasil penelitian. Kedudukannya sebagai peneliti dan sekaligus pengumpul data, maka peneliti harus terus berada dan terlibat langsung dalam penelitian dan obyek yang akan di teliti dengan maksud untuk mengumpulkan data terkait permasalahan yang di teliti.

Penelitian ini menggunakan rencana dan prosedur Penelitian Tindakan Kelas (PTK), Kurt Lewin (Kunandar, 2012: 42) menjelaskan bahwa penelitian tindakan adalah rangkaian langkah yang terdiri atas 
empat tahap, yakni perencanaan, tindakan, pengamatan dan refleksi.

Menurut Arikunto (Sangadji dan Sopiah, 2010:150) "bahwa tes adalah serentetan pertanyaan atau latihan serta alat lain yang digunakan untuk mengukur keterampilan, pengetahuan intelegensi, kemampuan, atau bakat yang di miliki oleh individu atau kelompok".

Menurut Sanjaya

"bahwa intrumen penelitian merupakan alat bantu bagi penelitian dalam pengumpulan data". Kualitas intrumen akan menetukan kualitas data yang terkumpul. Oleh karena itu, menyusun intrumen bagi kegiatan penelitan merupakan langkah penting yang harus dipahami oleh penelitian.

Menurut Kunandar (2012:128) data kualitatif yaitu : Data yang berupa informasi berbentuk kalimat yang memberikan “ gambaran tentang ekspresi siswa berkaitan dengan tingkat pemahaman terhadap suatu pelajaran (kognitif), pandangan atau sikap siswa terhadap metode belajar yang baru (afektif), aktivitas siswa mengikuti pelajaran, perhatian, antusias dalam belajar, kepercayaan diri, motivasi belajar, dan sejenisnya, dapat dianalisis secara kualitatif.

Menurut Kunandar (2012:128) data kuantifatif (nilai hasil belajar peseta didik) dapat dianalisiss secara deskriptif. Misalnya, mencari nilai rerata, persentasi keberhasilan belajar dan lain-lain. Hal ini dilakukan untuk mengetahui hasil belajar dalam pelajaran IPA peserta didik pada metode dan media pembelajaran yang diterapkan.

\section{HASIL DAN PEMBAHASAN}

Pada tahap ini peneliti melaksanakan tindakan pembelajaran menggunakan model Mind Mapping (Peta Pikiran) dan bantuan Media Audio Visual pada mata pelajaran IPA Kelas III SDN 3 Langkai PalangkaRaya.

Pengamatan observasi guru dan aktivitas peserta didik, observasi guru dan aktivitas peserta didik pada siklus I dapat dilihat pada tabel dan gambar berikut:

Tabel 1

Kegiatan Guru dan Aktivitas Peserta Didik

\begin{tabular}{|l|l|c|c|}
\hline No & $\begin{array}{l}\text { Observasi/ } \\
\text { Aktivitas }\end{array}$ & $\begin{array}{c}\text { Siklus } \\
\text { I }\end{array}$ & $\begin{array}{c}\text { Siklus } \\
\text { II }\end{array}$ \\
\hline 1 & Guru & 3,31 & 3,81 \\
\hline 2 & $\begin{array}{l}\text { Peserta } \\
\text { Didik }\end{array}$ & 3,10 & 3,77 \\
\hline
\end{tabular}

Gambar 1

Grafik Aktivitas Guru dan Peserta Didik

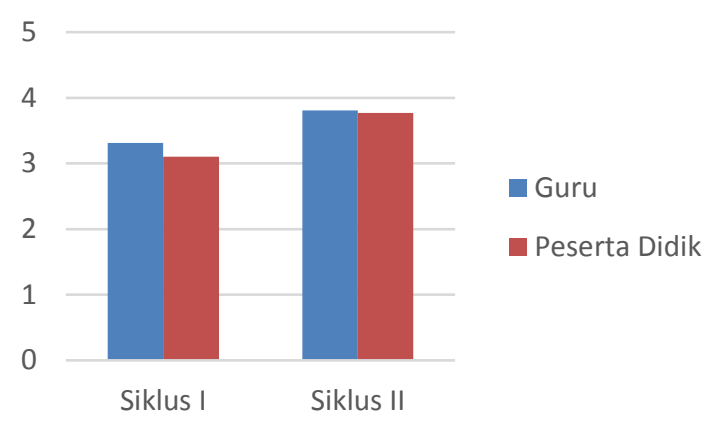

Adanya peningkatan hasil belajar dengan menggunakan model Mind Mapping (Peta Pikiran) dan bantuan Media Audio Visual pada mata pelajaran IPA Kelas III pada SDN 3 Langkai PalangkaRaya pada tahun pelajaran 2017/2018. Hal ini ditunjukkan dengan adanya peningkatan ketuntasan klasikal dari Siklus I ke Siklus II

\section{KESIMPULAN}

Aktifitas belajar peserta didik dalam pembelajaran IPA dengan menerapkan model Mind Mapping (Peta Pikiran) dan berbantuan media 
Audio Visual peserta didik kelas III di SDN-3 Langkai tahun pelajaran 2017/2018, menjadi baik dengan adanya keterlibatan peserta didik dalam proses pembelajaran dari siklus I yang memperoleh skor nilai rata-rata 77,91 dengan kriteria baik dan pada proses pembelajaran siklus II skor nilai aktivitas peserta didik meningkat, memperoleh nilai rata-rata 85 dengan kriteria sangat baik.

Adanya peningkatan hasil belajar IPA peserta didik setalah diajarkan dengan menerapkan model Mind Mapping (Peta Pikiran) dan berbantuan media Audio Visual pada peserta didik kelas III di SDN-3 Langkai Palangkaraya tahun pelajaran 2017/2018. Hal ini dapat diketahui pada tahap pre tes dengan nilai rata-rata yaitu 54,79 dengan ketuntasan klasikal 8,333 $\%$ mengalami peningkatan pada siklus I yakni mencapai rata-rata 77,91 dengan ketuntasan klasikal 83,33\%. Dan hasil yang dicapai peserta didik pada siklus II untuk nilai rata-rata lebih meningkat dari siklus sebelumnya yaitu mencapai rata-rata 85 dengan nilai ketuntasan klasikal yaitu $100 \%$.

\section{DAFTAR PUSTAKA}

Arikunto,S.dkk. (2010). Penelitian Tindakan Kekas. Jakarta : PT. Bumi Angkasa;

Depdiknas . (2013). Undang-undang No. 20 Tahun 2013, tentang Sistem Pendidikan Nasional. Jakarta : Depdiknas

Kunandar. (2012). Langkah Mudah Penelitian Tindakan Kelas Sebagai Pengembagan Profesi Guru. Jakarta: PT.RajaGrafindo Persada.

Wina Sanjaya. (2013). Penelitian Tindakan Kelas. Jakarta: Kencana PrenadaMedia Group. 